\title{
When to suspect occupational asthma
}

\author{
Catherine Lemière MD MSc
}

C Lemière. When to suspect occupational asthma. Can Respir J 2013;20(6):442-444.

Occupational asthma (OA) is a difficult diagnosis to make. The present review describes the work environments in which workers are at risk for developing $\mathrm{OA}$, the characteristics of the individuals in whom OA should be suspected and the investigation that can be performed to diagnose the condition. Accurately diagnosing $\mathrm{OA}$ is crucial because of the major social and economic consequences of this diagnosis on the patient.

Key Words: Diagnosis of occupational asthma; Occupational asthma; Risk factors for occupatinal asthma

\section{Quand soupçonner un asthme professionnel}

L'asthme professionnel (AP) est difficile à diagnostiquer. La présente analyse décrit les milieux de travail dans lesquels les travailleurs sont à risque d'AP, les caractéristiques des personnes chez qui on devrait soupçonner un $\mathrm{AP}$ et les examens à effectuer pour diagnostiquer le problème. Il est essentiel de bien diagnostiquer l'AP en raison des conséquences sociales et économiques considérables de ce diagnostic sur le patient. sthma is a common and costly chronic respiratory condition that $\mathrm{I}_{\text {affects }}>2$ million Canadians $\geq 12$ years of age (1). A systematic review of general population-based studies from various parts of the world published up to 2007 estimated that 17.6\% of adult-onset asthma was attributable to workplace exposures (2). Asthma is considered to be 'work related' when there is a relationship between the symptoms of asthma and the workplace. Work-related asthma encompasses occupational asthma (OA) and work-exacerbated asthma (3). OA refers to de novo asthma or the recurrence of previously quiescent asthma (ie, asthma as a child or in the distant past that has been in remission) induced by either sensitization to a specific substance, which is termed 'sensitizer-induced OA', or by exposure to an inhaled irritant at work, which is termed 'irritant-induced OA'. Work-exacerbated asthma refers to asthma triggered by various workrelated factors (eg, aeroallergens, irritants or exercise) in workers who are known to have pre-existing or concurrent asthma (ie, asthma that is occurring at the same time, but is not caused by workplace exposures) (3).

Detailed guidelines regarding the management of work-related asthma were published by a European Respiratory Society Task Force in 2012 (4). The aim of the present review was to focus on sensitizerinduced $\mathrm{OA}$ by describing the work environment and the clinical characteristics that may lead one to suspect sensitizer-induced OA in a worker with asthma; and summarizing the investigation that can be performed to diagnose sensitizer-induced $O A$.

\section{WORKPLACES AND OCCUPATIONAL AGENTS \\ ASSOCIATED WITH THE DEVELOPMENT OF OA}

A very large number $(>400)$ of substances used in the workplace can precipitate the development of sensitizer-induced OA (5). They are usually categorized into high-molecular-weight (HMW) and lowmolecular-weight (LMW) agents (Table 1). HMW agents are proteins of plant and animal origin, while LMW agents include chemicals, metals and wood dusts. Although several hundred agents have been described to cause OA, only a handful (ie, flour, diisocyanates, latex, persulphate salts, aldehydes, animals, wood dusts, metals and enzymes) usually account for the majority (50\% to $90 \%$ ) of reported cases of OA $(6,7)$. The distribution of causal agents may vary widely across geographical areas depending on the pattern of industrial activity $(6,8-13)$. The highest incidence rates of $\mathrm{OA}$ occur in bakers and pastry makers, other food processors, spray painters, hairdressers, wood workers, health care workers, cleaners, farmers, laboratory technicians and welders. The substances to which the worker is potentially exposed to at work can be verified against a comprehensive list of

TABLE 1

Examples of occupations and agents responsible of sensitizer-induced occupational asthma

\begin{tabular}{|c|c|c|}
\hline Occupation/industry & Agent & $\begin{array}{l}\text { Molecular } \\
\text { weight }\end{array}$ \\
\hline Flour mills, bakers, pastry makers & Cereals, flour (wheat, rye, barley, buckwheat) & High \\
\hline Health care workers, laboratory technicians & Latex & High \\
\hline Laboratory workers, farmers, sea food processing & Animals (mice, rats, cows, sea food) & High \\
\hline $\begin{array}{l}\text { Baking product production, bakers, detergent production, } \\
\text { pharmaceutical industry, food industry, health care workers }\end{array}$ & Enzymes (a-amylase, maxatase, alcalase, papain, bromelain, pancreatin, subtilisin) & High \\
\hline $\begin{array}{l}\text { Polyurethane production, plastic industry, insulation, molding, } \\
\text { spray painting }\end{array}$ & $\begin{array}{l}\text { Diisocyanates (toluene diisocyanate, methylene diphenyl-diisocyanate, } \\
\text { hexamethylene diisocyanate) }\end{array}$ & Low \\
\hline Metal refinery, metal alloy production, electroplating, welding & Metals (chromium, nickel, cobalt, platinum) & Low \\
\hline Health care workers, cleaners & Biocides (formaldehyde, glutaraldehyde, quaternary ammonium compounds) & Low \\
\hline $\begin{array}{l}\text { Adhesives, dental and orthopedic materials, sculptured } \\
\text { fingernails, printing inks, paints and coatings }\end{array}$ & Acrylates (cyanoacrylates, methacrylates, di- and triacrylates) & Low \\
\hline Hairdressers & Hair bleaching (persulfate salts), hair dyes (paraphenylenediamine) & Low \\
\hline Epoxy resin workers & Acid anhydride (phthalic, trimellitic, maleic, tetrachlorophthalic anhydrides) & Low \\
\hline Textile workers, food industry workers & Reactive dyes (reactive black 5 , pyrazolone derivatives, vinyl sulphones, carmine) & Low \\
\hline Sawmill workers, carpenters, cabinet and furniture makers & Wood dust (red cedar, iroko, obeche, oak and others) & Low \\
\hline
\end{tabular}

Department of Chest Medicine, Sacré-Coeur Hospital, Montreal, Quebec

Correspondence: Dr Catherine Lemiere, Department of Chest Medicine, Sacré-Coeur Hospital, 5400 Gouin West, Montreal, Quebec H4J 1 C5.

Telephone 514-338-2796, fax 514-338-3123, e-mail catherine.lemiere@umontreal.ca 
agents recognized to cause $\mathrm{OA}$ and the individual's employment can be searched on a list of at-risk occupations (3). Material safety data sheets can be requested from the workplace and may be of help in clarifying the presence of a workplace sensitizer. If the content of the causal agent is $<1 \%$, it may not be listed in the material safety data sheet. If available, the occupational health record and the industrial hygiene record from the company should also be reviewed. A comprehensive list of agents responsible for OA, as well as a list of occupations in which the exposure to those agents is encountered, can be found at <www.asthme.csst.qc.ca/info_med/index.html>.

\section{HOST-RELATED FACTORS PREDISPOSING TO THE DEVELOPMENT OF SENSITIZER-INDUCED OA}

As much as $20 \%$ of all cases of adult-onset asthma are due to occupational exposure. The precise factors that contribute to the development of OA in some, but not all, exposed individuals remain unknown. Various host markers have been implicated.

Atopy has been shown to be associated with sensitization to HMW agents in individuals with OA. For example, atopy was one of the main determinants for a specific sensitization to rodents in apprentices working in animal facilities (14) as well as for sensitization to latex in apprentices in dental hygiene (15). Pre-exposure sensitization to common allergens that are structurally similar to workplace allergens, such as pets of laboratory animal workers, could be a stronger risk factor for OA than atopy.

Smoking may also play a role in association with atopy in the risk for developing OA to some specific agents such as laboratory animals (16) and tetrachlorophtalic anhydride (17). However, the relationship between smoking and the development of clinical OA is weak (18).

The presence of airway hyper-responsiveness (AHR) $(19,20)$ and rhinitis $(20,21)$ before entering a workplace in which HMW agents are present is an independent risk factor for subsequent immunoglobulin E sensitization to these allergens. Furthermore, the development of occupational rhinitis during exposure often precedes the occurrence of OA $(22,23)$. However, the predictive value of work-related nasal symptoms is only $11.4 \%$ for the subsequent development of probable $\mathrm{OA}$ in workers exposed to laboratory animals over a follow-up period of 30 to 42 months.

Genetic factors likely play a role in the development of OA. Certain human leukocyte antigen class II molecules were found to be either risk factors for or protective factors against OA due to various LMW and HMW agents (24). Genes associated with T helper cell 2 cell differentiation may also play a role in the development of OA. Genes involved in the protection against oxidative stress, such as those coding for glutathione-S-transferase and N-acetyltransferase, have been associated with an increased risk of isocyanate-induced $\mathrm{OA}$ or a protective effect. Overall, the currently available information indicates that genetic markers have a low predictive value in identifying susceptible workers. In addition, there is convincing evidence that a wide variety of environmental factors can interact with genetic determinants to affect disease susceptibility.

\section{CLINICAL PRESENTATION SUGGESTIVE OF SENSITIZER-INDUCED ASTHMA}

Sensitizer-induced OA should be suspected in every worker with newonset asthma or in workers whose asthma has become difficult to control. Although OA has been described primarily in subjects who did not have asthma before their occupational exposure, approximately $20 \%$ of individuals with OA report having childhood asthma or asthma onset before entering the workforce $(25,26)$. Therefore, OA should not be ruled out based only on the timing between the onset of asthma and the beginning of the occupational exposure.

Although the respiratory symptoms (eg, wheezing, dyspnea, chest tightness, cough and sputum production) are similar to those encountered in non-work-related asthma, their occurrence is usually modulated by the work exposure. The symptoms can start at the beginning of the work shift or toward its end, or even after working hours, with

\section{TABLE 2}
Pooled estimates of sensitivity and specificity of skin prick testing, airway responsiveness and peak expiratory flow monitoring compared with specific inhalation challenge

\begin{tabular}{|c|c|c|}
\hline Test & Sensitivity & Specificity \\
\hline \multicolumn{3}{|c|}{ Skin-prick tests to occupational agent(s) } \\
\hline High molecular weight & $80.6(69.8-88.1)$ & $59.6(41.7-75.3)$ \\
\hline Low molecular weight & $72.9(59.7-83.0)$ & $86.2(77.4-91.9)$ \\
\hline \multicolumn{3}{|c|}{ Airway hyper-responsiveness (single test) } \\
\hline Low molecular weight & $66.7(58.4-74.0)$ & $63.9(56.1-71.0)$ \\
\hline High molecular weight & $79.3(67.7-87.6)$ & $51.3(35.2-67.2)$ \\
\hline Various agents & $83.7(66.8-92.9)$ & $48.4(25.9-71.6)$ \\
\hline \multicolumn{3}{|c|}{ Airway hyper-responsiveness (serial tests) } \\
\hline Low molecular weight & $67.7(42.6-85.3)$ & $65.6(41.1-84.0)$ \\
\hline Various agents & $50(35.5-64.5)$ & $66.8(53.3-78.0)$ \\
\hline \multicolumn{3}{|c|}{ Peak expiratory flow rate monitoring } \\
\hline Low molecular weight & $86.7(59.5-96.6)$ & $90(53.3-98.6)$ \\
\hline Various agents & $63.6(43.4-79.9)$ & $77.2(66.5-85.2)$ \\
\hline
\end{tabular}

Data presented as \% (95\% Cl)

remission or improvement during weekends and holidays. Rhinitis is associated with respiratory symptoms in the majority of cases of OA and often precedes the occurrence of the respiratory symptoms, especially with HMW agents. Although a thorough clinical and occupational history must be carefully recorded, the diagnosis of OA cannot be made only on the basis of a compatible history, which has a low positive predictive value (27). A comprehensive investigation should be performed to accurately diagnose OA.

\section{DIAGNOSTIC TESTS PERFORMED IN INDIVIDUALS WITH SUSPECTED SENSITIZER-INDUCED OA}

Immunological assessment

Although immunological tests are limited by the lack of standardized, commercially available reagents for skin and in vitro tests for diagnosing $\mathrm{OA}$, they bring useful information when available. The pooled sensitivity and specificity of skin-prick testing compared with specific inhalation challenges (SIC) is reported in Table 2 (28). Most in vitro tests used to assess specific sensitization to occupational chemicals remain research tools at present.

\section{Respiratory function tests}

In workers with a clinical and occupational history compatible with $\mathrm{OA}$, the diagnosis of asthma needs to be confirmed by documenting reversible airflow limitation and/or AHR (29). However, the lack of AHR does not exclude the diagnosis of $\mathrm{OA}$ in individuals who have been removed from exposure. The work-relatedness of asthma should be assessed through serial measurements of peak expiratory flow (PEF) and/or AHR at work and off work, and/or SIC in the laboratory or at the workplace. The pooled estimates of sensitivity and specificity of the measure of AHR or PEF are reported in Table 2.

\section{SIC tests}

SIC tests consist of exposing indviduals to the suspected occupational agent in the laboratory and/or the workplace (30). These tests are considered to be the gold standard; however, they are time consuming and require specialized facilities available in only a few centres. SIC tests are especially useful when: the diagnosis of OA remains in doubt after serial monitoring of PEF or AHR; a patient clearly has OA, but the causal agent needs to be identified; a new agent is suspected of causing $\mathrm{OA}$; and the patient cannot be returned to the hazardous workplace. A false-negative response may occur if the wrong agent is used or if the exposure conditions are not comparable with those in the workplace. 


\section{Noninvasive measures of airway inflammation}

Sputum cell counts: An increase in sputum eosinophil counts has been shown to occur $7 \mathrm{~h}$ after exposure to occupational agents and persist $24 \mathrm{~h}$ after exposure (31). An increase in sputum eosinophil counts $>3 \%$ after the first day of exposure during SIC appears to be one of the most accurate parameters for predicting the development of an asthmatic response on subsequent exposures, with a sensitivity of $67 \%$ and a specificity of $97 \%$ (32).

Exhaled nitric oxide: Previous studies have reported that an increase in fractional exhaled nitric oxide (FeNO) was not uniform among subjects who experienced a positive asthmatic reaction during SIC (33). The measurement of $\mathrm{FeNO}$ as a surrogate marker for eosinophilic airway inflammation is simple and feasible in almost all patients, and provides immediate results, but is more sensitive to confounding factors, such as

\section{REFERENCES}

1. Statistics Canada. Asthma by age group and sex. 2010. $<$ www.statcan.gc.ca/tables-tableaux/sum-som/101/cst01/health49aeng.htm > (Accessed June 17, 2013).

2. Toren K, Blanc PD. Asthma caused by occupational exposures is common - a systematic analysis of estimates of the populationattributable fraction. BMC Pulm Med 2009;9:7.

3. Tarlo SM, Balmes J, Balkissoon R, et al. Diagnosis and management of work-related asthma: American College Of Chest Physicians Consensus Statement. Chest 2008;134(3 Suppl):1S-41S.

4. Baur X, Aasen TB, Burge PS, et al. The management of workrelated asthma guidelines: A broader perspective. Eur Respir Rev 2012;21:125-39.

5. Baur X, Bakehe P. Allergens causing occupational asthma: An evidence-based evaluation of the literature. Int Arch Occup Environ Health 2013 April 18 (Epub ahead of print).

6. Vandenplas O, Lantin AC, D'Alpaos V, et al. Time trends in occupational asthma in Belgium. Respir Med 2011;105:1364-72.

7. Vandenplas O. Occupational asthma: Etiologies and risk factors. Allergy Asthma Immunol Res 2011;3:157-67.

8. Karjalainen A, Kurppa K, Virtanen S, Keskinen H, Nordman H. Incidence of occupational asthma by occupation and industry in Finland. Am J Ind Med 2000;37:451-8.

9. Ameille J, Pauli G, Calastreng-Crinquand A, et al. Reported incidence of occupational asthma in France, 1996-99: The ONAP programme. Occup Environ Med 2003;60:136-41.

10. Reinisch F, Harrison RJ, Cussler S, et al. Physician reports of workrelated asthma in California, 1993-1996. Am J Ind Med 2001;39:72-83.

11. McDonald JC, Chen Y, Zekveld C, Cherry NM. Incidence by occupation and industry of acute work related respiratory diseases in the UK, 1992-2001. Occup Environ Med 2005;62:836-42.

12. Piipari R, Keskinen H. Agents causing occupational asthma in Finland in 1986-2002: Cow epithelium bypassed by moulds from moisture-damaged buildings. Clin Exp Allergy 2005;35:1632-7.

13. Orriols R, Isidro I, Abu-Shams K, et al. Reported occupational respiratory diseases in three Spanish regions. Am J Ind Med 2010;53:922-30.

14. Gautrin D, Ghezzo H, Infante-Rivard C, Malo J-L. Incidence and determinants of IgE-mediated sensitization in apprentices: A prospective study. Am J Respir Crit Care Med 2000;162:1222-8.

15. Archambault S, Malo J, Infante-Rivard C, Ghezzo H, Gautrin D. Incidence of sensitization, symptoms and probable occupational rhinoconjunctivitis and asthma in apprentices starting exposure to latex. J Allergy Clin Immunol. 2001;107:921-3.

16. Venables K, Upton J, Hawkins E, Tee R, Longbottom J, Newman-Taylor A. Smoking, atopy and laboratory animal allergy. Br J Ind Med 1988;45:667-71.

17. Venables K. Low molecular weight chemicals, hypersensitivity, and direct toxicity: The acid anhydrides. Br J Ind Med 1989;46:222-32.

18. Maestrelli P, Schlunssen V, Mason P, Sigsgaard T. Contribution of host factors and workplace exposure to the outcome of occupational asthma. Eur Respir Rev 2012;21:88-96. smoking, atopy and treatment with inhaled corticosteroids, compared with sputum eosinophil counts (34). Additional evidence is needed before recommending the use of $\mathrm{FeNO}$ in the routine investigation of OA.

\section{CONCLUSION}

OA should be suspected in every worker with new-onset asthma or whose asthma becomes difficult to control. Although gathering a thorough clinical and occupational history is essential, a comprehensive investigation should be performed to demonstrate the relationship between the occurrence of asthma and the exposure to a specific agent at the workplace. Making an accurate diagnosis of $\mathrm{OA}$ is crucial because of the significant social and financial consequences associated with this diagnosis.

19. Gautrin D, Infante-Rivard C, Ghezzo H, Malo JL. Incidence and host determinants of probable occupational asthma in apprentices exposed to laboratory animals. Am J Respir Crit Care Med 2001;163:899-904.

20. Gautrin D, Ghezzo H, Infante-Rivard C, et al. Long-term outcomes in a prospective cohort of apprentices exposed to high-molecularweight agents. Am J Respir Crit Care Med 2008 15;177:871-9.

21. Gautrin D, Ghezzo H, Infante-Rivard C, Malo JL. Host determinants for the development of allergy in apprentices exposed to laboratory animals. Eur Respir J 2002;19:96-103.

22. Gautrin D, Ghezzo H, Infante-Rivard C, Malo JL. Natural history of sensitization, symptoms and occupational diseases in apprentices exposed to laboratory animals. Eur Respir J 2001;17:904-8.

23. Elliott L, Heederik D, Marshall S, Peden D, Loomis D. Progression of self-reported symptoms in laboratory animal allergy. J Allergy Clin Immunol 2005;116:127-32.

24. Bernstein DI. Genetics of occupational asthma. Curr Opin Allergy Clin Immunol 2011;11:86-9.

25. Larbanois A, Jamart J, Delwiche J, Vandenplas O. Socioeconomic outcome of subjects experiencing asthma symptoms at work. Eur Respir J 2002;19:1107-13.

26. Lemiere C, Boulet LP, Chaboillez S, et al. Work-exacerbated asthma and occupational asthma: Do they really differ? J Allergy Clin Immunol 2013;131:704-10.

27. Malo J, Ghezzo H, L'Archevêque J, Lagier F, Perrin B, Cartier A. Is the clinical history a satisfactory means of diagnosing occupational asthma? Am Rev Respir Dis 1991;143:528-32.

28. Beach J, Russell K, Blitz S, et al. A systematic review of the diagnosis of occupational asthma. Chest 2007;131:569-78.

29. Lougheed MD, Lemiere C, Ducharme FM, et al. Canadian Thoracic Society 2012 guideline update: Diagnosis and management of asthma in preschoolers, children and adults. Can Respir J 2012;19:127-64.

30. Vandenplas O, Cartier A, Malo J. Occupational challenge tests. Bernstein IL, Chan-Yeung M, Malo JL, Bernstein DI, eds. In: Asthma in the Workplace, 3rd edn. New York: Taylor \& Francis, 2006:227-52

31. Obata H, Cittrick M, Chan H, Chan-Yeung M. Sputum eosinophils and exhaled nitric oxide during late asthmatic reaction in patients with western red cedar asthma. Eur Respir J 1999;13:489-95.

32. Vandenplas O, D'Alpaos V, Heymans J, et al. Sputum eosinophilia: An early marker of bronchial response to occupational agents. Allergy 2009;64:754-61.

33. Quirce S, Lemiere C, de Blay F, et al. Noninvasive methods for assessment of airway inflammation in occupational settings. Allergy 2010;65:445-58.

34. Schleich FN, Seidel L, Sele J, et al. Exhaled nitric oxide thresholds associated with a sputum eosinophil count $>1=3 \%$ in a cohort of unselected patients with asthma. Thorax 2010;65:1039-44. 


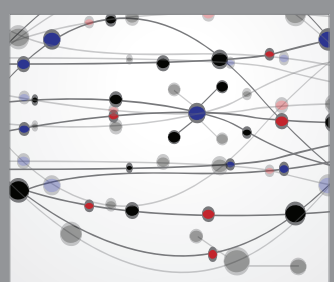

The Scientific World Journal
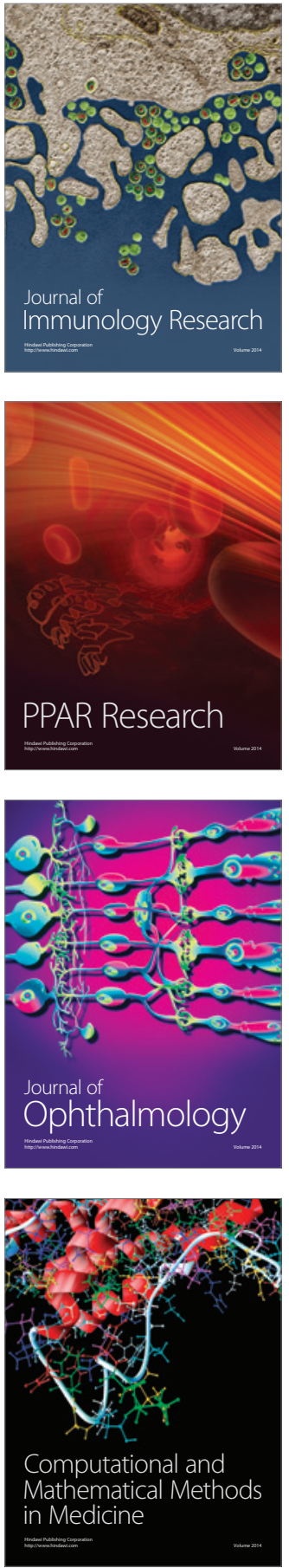

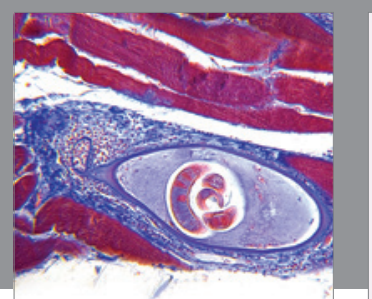

Gastroenterology Research and Practice

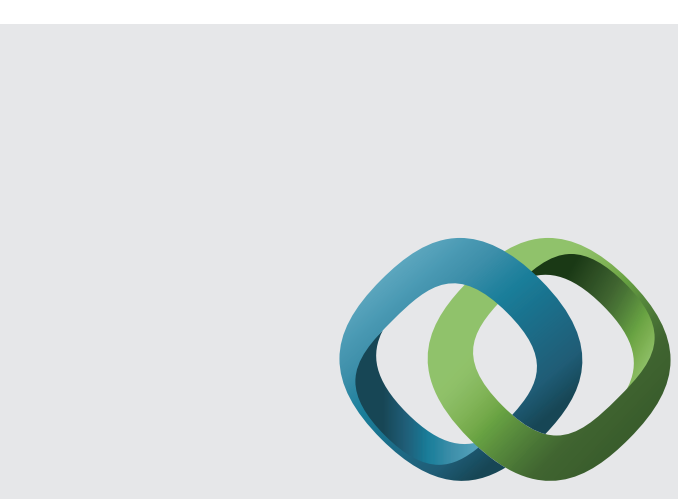

\section{Hindawi}

Submit your manuscripts at

http://www.hindawi.com
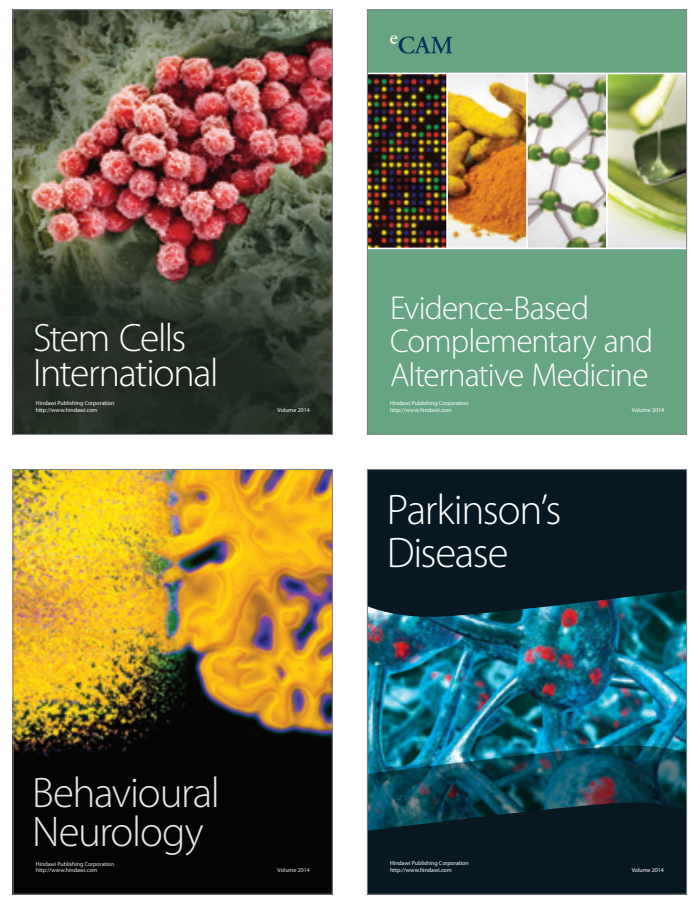
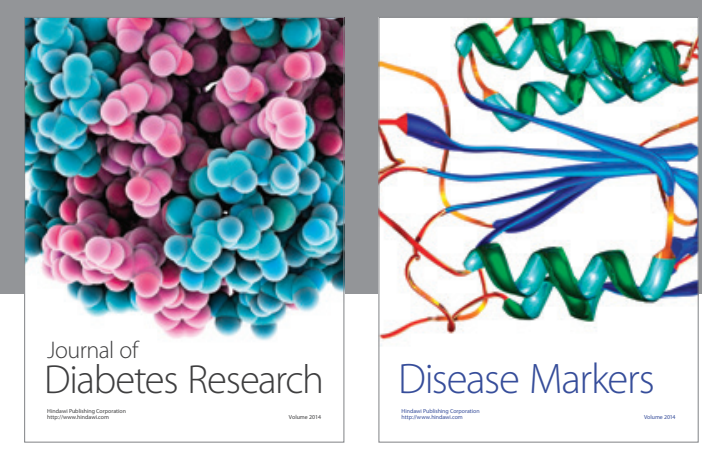

Disease Markers
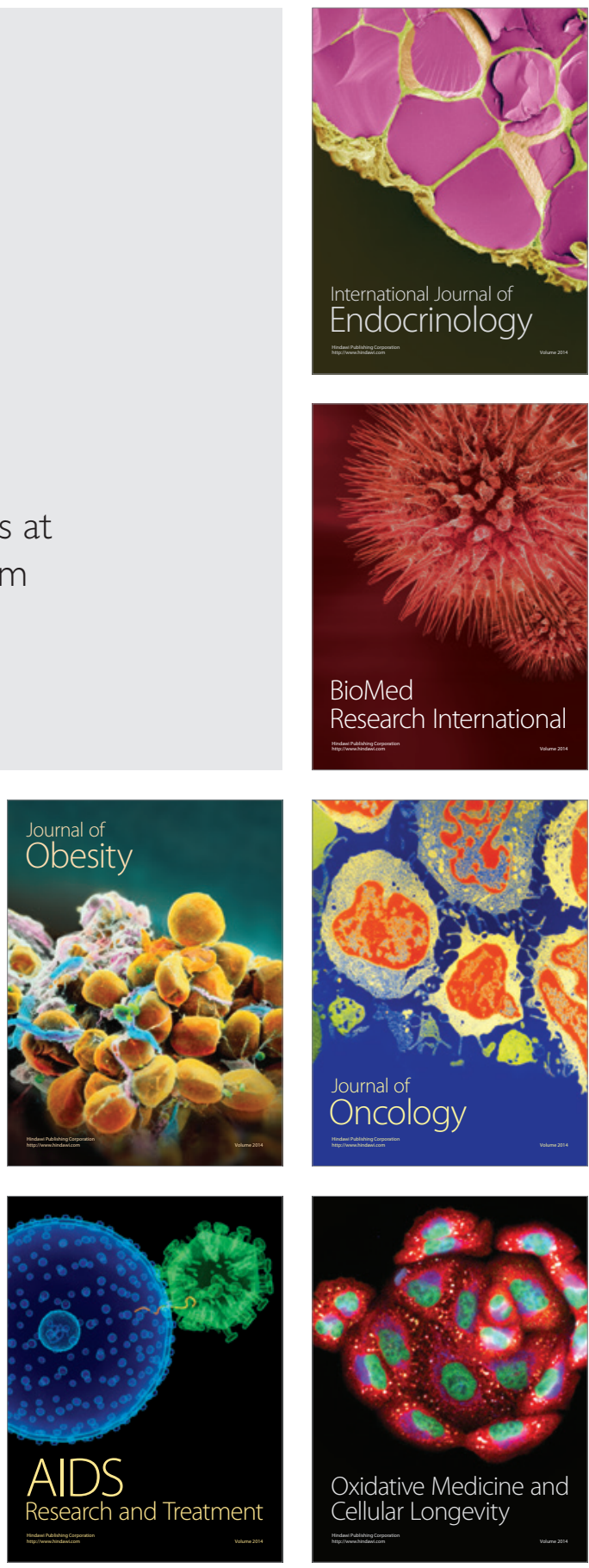